\title{
Evaluation of the effectiveness of ultrasound-guided transversus abdominis plane block for chronic pain after lower abdominal surgery
}

\section{Alt abdominal cerrahi sonrası gelişen kronik ağrı tedavisinde ultrason eşliğinde transversus abdominis plan bloğunun etkinliğinin değerlendirilmesi}

\author{
'Ümit Akkemik (D), ${ }^{2}$ Dostali Aliyev (D), ${ }^{2}$ Güngör Enver Özgencil (D) \\ 'Department of Algology, Konya City \\ Hospital, Konya, Turkey \\ 2Department of Algology, Ankara \\ University Faculty of Medicine, Ankara, \\ Turkey \\ Correspondence \\ Ümit Akkemik, Department of Algology \\ Konya City Hospital, Konya, Turkey \\ E-Mail: umitak87@gmail.com

\section{How to cite?} \\ Akkemik Ü, Aliyev D, Özgencil G.

\begin{abstract}
Aim: This study aimed to evaluate the effectiveness of ultrasound-guided transversus abdominis plane (TAP) block in patients diagnosed with chronic pain after undergoing lower abdominal surgery.

Methods: Patients who were admitted to the pain medicine clinic between January 1, 2016, and January 1, 2020, and underwent TAP block with the diagnosis of chronic pain after undergoing lower abdominal surgery were retrospectively analyzed. The visual analog scale (VAS) score was measured before the procedure and at the 1-month and 3-month follow-ups.

Results: The proportion of patients with a reduction in VAS scores of $>50 \%$ after TAP block application was $50 \%$ at the 1-month follow-up and $72.5 \%$ at the 3-month follow-up. The changes in the VAS score was found to be statistically significant $(p<0.05)$.

Conclusion: Although ultrasound-guided TAP block seems to be an effective treatment method for chronic pain after lower abdominal surgery, further studies and clinical trials investigating different types of surgeries and including a larger number of patients are warranted.
\end{abstract} Evaluation of the effectiveness of ultrasound-guided transversus abdominis plane block for chronic pain after lower abdominal surgery. Genel Tip Derg. 2022;32(1):27-31.

\section{Introduction}

Keywords: Chronic postoperative pain, abdominal wall, Pain Management, Nerve block

öz

Amaç: Calışmamızda alt abdominal cerrahi sonrası gelişen kronik ağıı tanısı konulan hastalarda ultrason rehberliğinde transversus abdominis plan bloğunun etkinliğinin değerlendirilmesi amaçlanmıştır.

Metod: 1 Ocak 2016-1 Ocak 2020 tarihleri arasında ağı polikliniğine başvuran ve alt abdominal cerrahi sonrası kronik ağrı tanısı ile TAP blok uygulanan hastalar geriye dönük

olarak incelendi. Hastaların işlem öncesi, işlem sonrası 1.ay ve 3. Ay Vizüel analog skala (VAS) değerleri karşılasstırıldı.

Bulgular: TAP blok uygulaması sonrası VAS skorlarinda $>\% 50$ azalma olan hastaların oranı 1 aylik takipte $\% 50$ ve 3 aylık takipte $\% 72,5$ idi. VAS skorlarındaki değişiklikler istatistiksel olarak anlamlı bulundu $(p<0.05)$.

Sonuç: Ultrason rehberliğinde TAP blok alt abdominal cerrahi sonrası kronik ağrıda efektif bir tedavi yöntemi gibi görünmekle beraber, farklı ameliyat türlerinde ve daha fazla hastanın yer aldığı ileri çalışmalar ve klinik denemelerin yapılması gerekmektedir.

Anahtar Kelimeler: kronik postoperatif ağı̆, abdominal duvar, ağrı tedavisi

Abdominal surgery is one of the most frequently caused by surgical procedures remains an important performed surgeries worldwide. Laparotomy and clinical problem that severely affects postoperative laparoscopic approaches are commonly used in rehabilitation.

this surgery (1). The most common reasons for visits to

the hospital in patients with chronic pain syndrome Persistent postoperative pain is defined by the after abdominal surgery are persistent pain in the International Association for the Study of Pain as abdomen, genital and perineal regions (2). While most clinical discomfort lasting $>3$ months postoperatively abdominal surgeries are performed with excellent without other causes of pain, such as chronic infection outcomes and minimal morbidity, a small proportion or pain from a chronic condition prior to surgery (3). of patients experience postoperative discomfort and The incidence of postoperative acute or chronic pain pain, thereby limiting their activity and productivity, varies according to individuals and procedures. In a increasing healthcare utilization, and reducing study that evaluated persistent pain lasting 12 months their quality of life due to their individual and social postoperatively, the incidence of moderate-to- severe outcomes. Complete clinical recovery without postoperative pain in patients was $11.8 \%$, the incidence complications is important for patients, and pain of severe pain (numerical rating scale $\geq 6$ ) was $2.2 \%$, and 
the incidence of neuropathic pain was $35.4 \%-57.1 \%$ (4).In the literature, the incidence rates reported in studies are classified according to the presence of preoperative pain or the severity of postoperative pain (Table 1).

Table 1. Incidence of Persistent Postsurgical Pain according to Surgical Procedure (3)

\section{Cesarean section $15.4 \%$ \\ Cholecystectomy 3 to $56 \%$ \\ Hernia repair 5 to $35 \%$ \\ Hysterectomy 5 to $32 \%$}

Various mechanisms for the etiology of postoperative chronic pain have been proposed. The most widely accepted mechanism is the activation of highthreshold peripheral sensory neurons or neuropathic pain caused by inflammation or direct nerve injury at or near the surgical site. Neuroplastic changes in the peripheral and central nervous systems in response to acute postoperative pain have been suggested to play an important role in the development of postoperative chronic pain syndrome (5). Treatment protocols generally include oral or topical nonsteroidal anti-inflammatory drugs (NSAIDs), antidepressants, and anticonvulsant drugs. However, interventional minimally invasive procedures (nerve block and neurolysis) and revision surgery may be required in patients in whom adequate pain reduction cannot be achieved with conventional drug therapy. Nerve blocks are considered among the treatment options for postoperative pain because of their reproducibility $(6,7)$.

Anatomically, the spinal nerves from T7 to T11 run along the neurovascular plane that passes between the internal oblique and transverse abdominis in the anterior abdominal wall and is called the transversus abdominis plane (TAP). L1 (ilioinguinal and iliohypogastric) and T12 (subcostal nerve) also pass in the same plane (8). TAP block was first reported by Rafi et al., who described the traditional blind spot technique using Petit's lumbar triangle in 2001 (9). The increased prevalence of ultrasound guidance has enabled physicians performing TAP block to identify the appropriate tissue plane and perform the block with greater accuracy under direct visualization.

In this article, we discuss the effectiveness of TAP block applied using ultrasound guidance for patients diagnosed with chronic pain after undergoing lower abdominal surgery.

\section{Methods}

This study was performed with the approval of the Non Interventional Clinical Research Ethical Committee of the local ethics committee (reference number: i5-33021). In this single-center study, the medical records of patients who applied to our clinic between January 1, 2016 and January 1, 2020 with the diagnosis of postoperative chronic pain and underwent TAP block were reviewed retrospectively. In this retrospective study, we reviewed the charts of 40 chronic abdominal pain patients treated TAP blocks after other forms of pain management had failed.

In our clinic, TAP block is performed with the lateral approach under the guidance of USG. After providing the necessary antiseptic conditions in the supine position, the linear probe is placed at the midpoint of the distance between the costal border and the iliac crest. The ideal image is obtained by moving the probe cephally or caudally. The needle is placed in the same plane with the ultrasound probe (in-plane technique) (10). As the needle tip passes through the muscle layers and fascias, a fascial click is experienced as in the blind technique, and the needle tip is advanced in a controlled manner under ultrasound guidance. After the second click is experienced (after passing the fascia of the internal oblique muscle), a $0.5-1 \mathrm{ml}$ test dose is applied to determine the localization of the needle tip. Subsequently, the localization site is confirmed and aspirated at frequent intervals, and the injectable is administered into the neurofacial plane. In patients with obesity, it may not always be easy to distinguish the three muscle layers from each other because of the large amount of cutaneous-subcutaneous adipose tissue. In this case, it is important to keep in mind that the internal oblique muscle is considered as the thickest and the transversus abdominis muscle as the thinnest (11).

The study included patients in whom chronic abdominal wall pain persisted for at least 3 months after lower abdominal surgery, those who did not achieve benefits despite receiving medical treatment (NSAIDs, anticonvulsants, or antiepileptic drugs), those without organic pathologies (such as infection or hematoma) to explain the cause of pain, and those who underwent TAP block and were followed up for at least 3 months postoperatively. Patients who underwent tap block but were missing in their subsequent records were excluded from the study.

In our clinic, the pain levels of patients after TAP block are questioned once a month for 1-3 months, either by inviting them to the hospital or by calling them. Patients' data, including age, sex, body mass index (BMI), pain localization, and previous surgery, were recorded. Visual analog scale (VAS) score was recorded at the first admission as well as at the first and third months postoperatively, and the changes were compared using statistical analysis.

\section{Statistical analysis}

Statistical analysis was performed using SPSS 11.5 software for Windows. Descriptive statistics, including mean, standard deviation, median, and minimummaximum values of numerical variables, were used. Statistical significance was accepted at a p-value of $<0.05$. frequency and percentage values were used for categorical variables. Variances in VAS score before 
and after procedure was analyzed using Friedman's two-way test.

\section{Results}

TAP block was applied in a total of 56 patients upon their admission to the pain medicine department, according to the retrospective analysis. Sixteen of these patients were excluded because of the inaccessibility of their follow-up records. Of the 40 patients included in this study, 37,5\% (15 patients) were female and $62,5 \%$ (25 patients) were male. The patients' mean age was 48.4 (20-78) years, mean height was $169.5 \mathrm{~cm}$ (minimum, $153 \mathrm{~cm}$; maximum, $183 \mathrm{~cm}$ ), mean weight was $74.8 \mathrm{~kg}$ (minimum, $52 \mathrm{~kg}$; maximum, $105 \mathrm{~kg}$ ), and mean BMI was 25.2 (minimum, 18.8; maximum, 43.7).

Table 2 shows the patients' data, including age, sex, height, BMl, and demographic characteristics. Information regarding the surgical procedures of the patients is shown in Table 3.

Table 2. Patients' Data Before Interventional Procedure

$\begin{array}{lll} & \text { mean } \pm \text { sd } & \text { min.-max. } \\ \text { Age (years) } & 49.4 \pm 18.3 & 20-78 \\ \text { Height }(\mathrm{cm}) & 169.5 \pm 6.6 & 153-183 \\ \text { Weight }(\mathrm{kg}) & 74.8 \pm 11.8 & 52-105 \\ \begin{array}{l}\text { Body Mass Index } \\ \text { (BMI) }\end{array} & 25.2 \pm 4.6 & 18.8-43.7\end{array}$

sd:standard deviation; min: minimum value;max: maximum value

Table 3. Surgical Indication of The Patients Before Interventional Procedure

\begin{tabular}{|c|c|c|}
\hline Operation & Number of patients & Percent (\%) \\
\hline Appendectomy & 3 & 7.5 \\
\hline $\begin{array}{l}\text { Laparoscopic left } \\
\text { hemicolectomy }\end{array}$ & 4 & 10 \\
\hline $\begin{array}{l}\text { Laparoscopic } \\
\text { ectopic pregnancy } \\
\text { termination }\end{array}$ & 2 & 5 \\
\hline $\begin{array}{l}\text { Laparoscopic } \\
\text { ovarian cyst excision }\end{array}$ & 3 & 7.5 \\
\hline $\begin{array}{l}\text { Laparoscopic total } \\
\text { hysterectomy }\end{array}$ & 1 & 2.5 \\
\hline $\begin{array}{l}\text { Total abdominal } \\
\text { hysterectomy- } \\
\text { bilateral }\end{array}$ & 2 & 5 \\
\hline $\begin{array}{l}\text { Right inguinal hernia } \\
\text { repair }\end{array}$ & 9 & 22.5 \\
\hline $\begin{array}{l}\text { Left inguinal hernia } \\
\text { repair }\end{array}$ & 9 & 22.5 \\
\hline Cesarean section & 3 & 7.5 \\
\hline $\begin{array}{l}\text { Robotic } \\
\text { prostatectomy }\end{array}$ & 4 & 10 \\
\hline Total & 40 & 100 \\
\hline
\end{tabular}

Table 4. Pain Localization of The Patients

\begin{tabular}{|c|c|c|}
\hline Pain localization & Number of patients & Percent (\%) \\
\hline $\begin{array}{l}\text { Bilateral lower } \\
\text { quadrant }\end{array}$ & 3 & 7.5 \\
\hline Right lower quadrant & 7 & 17.5 \\
\hline Right inguinal region & 12 & 30 \\
\hline Left lower quadrant & 7 & 17.5 \\
\hline Left inguinal region & 11 & 27.5 \\
\hline Total & 40 & 100 \\
\hline
\end{tabular}

Table 5. VAS score change

$\begin{array}{lll}\begin{array}{l}\mathrm{N}=40 \\ \text { Before the } \\ \text { procedure }\end{array} & \text { mean } \pm \text { sd } & \\ \begin{array}{l}\text { Post-procedure } \\ 1 \text { month }\end{array} & 3.8 \pm 0.8 & \\ 3 \text { months } & 3.4 \pm 1.1 & \mathrm{p}=0.000 \\ & & \mathrm{p}=0.000\end{array}$

sd:standard deviation " $p<0.05$

Table 6. Drug usage information of the patients before and after the procedure

\begin{tabular}{|c|c|c|}
\hline $\begin{array}{l}\text { Total number } \\
\text { of patients }\end{array}$ & $\begin{array}{l}\text { Pre-procedure drug } \\
\text { use information }\end{array}$ & $\begin{array}{l}\text { Post-procedure drug use } \\
\text { information (3th month } \\
\text { after the procedure) }\end{array}$ \\
\hline 5 & $\begin{array}{l}\text { Gabapentin } 800 \mathrm{mg} \\
\text { p.o. (q8h) }\end{array}$ & $\begin{array}{l}\text { Gabapentin } 800 \mathrm{mg} \\
\text { p.o. (q8h) }\end{array}$ \\
\hline 8 & $\begin{array}{l}\text { Gabapentin } 800 \mathrm{mg} \\
\text { p.o. (q8h) }\end{array}$ & $\begin{array}{l}\text { Gabapentin } 300 \text { mg } \\
\text { p.o. (q8h) }\end{array}$ \\
\hline 7 & $\begin{array}{l}\text { Gabapentin } 800 \mathrm{mg} \\
\text { p.o. (q8h) }\end{array}$ & - \\
\hline 10 & $\begin{array}{l}\text { Amitriptyline } 25 \mathrm{mg} \\
\text { p.o. (q.d.) }\end{array}$ & $\begin{array}{l}\text { Amitriptyline } 25 \text { mg p.o. } \\
\text { (q.d.) }\end{array}$ \\
\hline
\end{tabular}

p.o. per os, mg-milligram, q8h- every eight hours, q.d.- once a day.

Table 7. Opioid use information of patients before and after the procedure

\begin{tabular}{lll} 
Drug & $\begin{array}{l}\text { Number } \\
\text { of } \\
\text { patients } \\
\text { (n) }\end{array}$ & $\begin{array}{l}\text { Persentage } \\
\text { of total } \\
\text { patients (\%) }\end{array}$ \\
$\begin{array}{l}\text { Number of patients using opioids } \\
\text { before the procedure }\end{array}$ & 21 & 52,5 \\
$\begin{array}{l}\text { Number of patients who did not use } \\
\text { opioids before the procedure }\end{array}$ & 19 & 47,5 \\
$\begin{array}{l}\text { Post-procedure opioid use (3th month } \\
\text { after the procedure) }\end{array}$ & & \\
$\begin{array}{l}\text { Using } \\
\text { stop using }\end{array}$ & - & - \\
\hline
\end{tabular}


Table 8. NSAID use information of patients before and after the procedure

$\begin{array}{lcc}\text { Drug } & \begin{array}{l}\text { Number of } \\ \text { patients ( } \mathbf{n} \text { ) }\end{array} & \begin{array}{l}\text { Persentage } \\ \text { of total } \\ \text { patients (\%) }\end{array} \\ \begin{array}{l}\text { Number of patients using NSAID } \\ \text { before the procedure }\end{array} & 32 & 80 \\ \begin{array}{l}\text { Number of patients who did not use } \\ \text { NSAID before the procedure }\end{array} & 8 & 20 \\ \begin{array}{l}\text { Post-procedure NSAID use (3th month } \\ \text { after the procedure) }\end{array} & & \\ \begin{array}{l}\text { Using } \\ \text { stop using }\end{array} & 10 & 25 \\ \end{array}$

The pain localization of the patients was in the lower abdomen and was usually unilateral (Table 4). TAP block was applied bilaterally in 3 patients, on the right side in 19 patients, and on the left side in 18 patients under the ultrasound guidance.

A total of $8 \mathrm{mg}$ of dexamethasone and $18 \mathrm{ml}$ of $2 \%$ prilocaine mixture were injected into the patients who underwent unilateral TAP block. Patients who underwent bilateral TAP block were injected with a mixture of $8 \mathrm{mg}$ of dexamethasone and $19 \mathrm{ml}$ of $2 \%$ prilocaine on each side.

While the mean VAS score before the procedure was 6.9, the VAS scores 1 month and 3 months after the procedure were 3.8 and 3.4 , respectively. The changes in the VAS score were found to be statistically significant $(p<0.05)$ (Table 5).

No complications (local anesthetic toxicity, liver, spleen, kidney laceration, and femoral nerve damage) were recorded in any of the patients. At the 3-month follow-up, it was determined that 5 of the 20 patients who used gabapentin $800 \mathrm{mg}$ three times a day before the procedure continued the drug at the same dose, whereas 8 patients used gabapentin $300 \mathrm{mg}$ three times a day and seven patients did not use the drug (Table 6). It was determined that 10 patients used the same dose of amitriptyline before and after the procedure. Since our study patients used opioid and non-steroidal anti-inflammatory drugs from different groups, these drugs could not be standardized by us (Table 7 and 8). None of the patients were using opioid drugs at the 3-month follow-up.

\section{Discussion}

In our study, the proportion of patients with a reduction in VAS score of $>50 \%$ was $50 \%$ at 1 - month followup and $72.5 \%$ at the 3 -month follow-up. This study indicated that administering TAP block to patients with chronic pain after lower abdominal surgery without causing any complications or side effects.

Persistent postoperative pain is one of the most common complications of surgery and is a severe social problem. Chronic abdominal pain, which can persist for months after initial onset, can be particularly difficult to manage. Treatment options include anticonvulsants, antidepressants, topical medications such as lidocaine gel, multidisciplinary rehabilitation programs, complementary medicine, and opioids in the presence of severe pain. Depending on the location of pain in patients experiencing chronic pain resistant to medical therapy, a nerve block in the relevant innervation area may be feasible. A mixture of local anesthetics and glucocorticoids is commonly used. Nerve blocks can stop the transmission of pain signals, inhibit neuroinflammation, and promote the recovery of neural functions (12).

In the literature, TAP block is mostly focused on as an anesthetic method in abdominal surgeries. TAP block can be used in surgical procedures involving the lower abdominal region, such as cesarean section (13), hernia repair $(14,15)$, appendectomy (16), and abdominal hysterectomy (17). In a meta-analysis of studies investigating postoperative pain management after cesarean section in which 524 patients in nine studies were evaluated, although the benefits of TAP block were not clearly proven in cases where it was applied after spinal anesthesia using opioids, it was emphasized that TAP block significantly contributed to postoperative pain control if applied after spinal anesthesia without intrathecal opioids (18). However, these studies show the efficacy of TAP block in postoperative acute pain.

Recent studies have shown that TAP block can be effective for the treatment of chronic abdominal wall pain. In a recently published study, TAP block was applied to 30 patients with chronic abdominal pain and improvement was reported in $79.5 \%$ of the patients (19). They reported that a significant decrease in the use of gabapentin was reported after the procedure compared to the pre-procedure and suggesting potential effectiveness in pain management.

TAP blocks have potential for both diagnostic and therapeutic use for chronic pain, particularly as they are related to chronic postoperative pain (20). For patients with chronic pain after abdominal surgery, it may be difficult to determine whether the pain is visceral or somatosensory. Pain relief following TAP block may help confirm the somatosensory origin of the symptoms (i.e., whether they are related to the superficial tissues or parietal peritoneum). Pain relief following TAP block is either due to a "hydrodissection" effect or the effect of a corticosteroid or local anesthetic agent. The duration of action of the agents selected for injection in our study was shorter than 3 months. Additional research is needed to assess this issue.

Although the complication rate after tap block is low, case reports about frightening complications such as local anesthetic toxicity, liver, spleen, kidney laceration, and femoral nerve damage are available in the literature $(21,22)$. Performing the tap block under ultrasound guidance will reduce the complication rate. In our study, no complications were recorded. 


\section{Limitation}

The main limitation of this study is the retrospective design and small number of patients. Since it is a retrospective study, the use of drugs by the patients could not be limited.

\section{Conclusion}

In our study, ultrasound guided TAP block was successfully applied in the management of chronic postoperative pain after lower abdominal surgery. Post-procedure pain levels of the patients decreased and their quality of life increased. The drug doses used decreased, and some patients did not need analgesic drugs after the procedure. Ultrasound-guided TAP block appears to be safe and effective, provided that the practicing experts have adequate training in the techniques to be employed. Effective management of chronic postoperative pain not only reduces the discomfort caused by pain but also improves patients' quality of life and physical activity.

Disclosures: There is no conflict of interest for all authors. Acknowledgements: None.

Funding: None.

\section{References}

1. Gupta A, Gandhi K, Viscusi ER. Persistent postsurgical pain after abdominal surgery. Tech Reg Anesth Pain Manage 201 1;15(3):140-6.

2. Crombie IK, Davies HT, Macrae WA. Cut and thrust: antecedent surgery and trauma among patients attending a chronic pain clinic. Pain. 1998;76(1-2):167-171.

3. Macrae, W.A. and Davies, H.T.O. (1999) Chronic Postsurgical Pain. In: Crombie, I.K., Ed., Epidemiology of Pain, IASP Press, Deattle, 125-142

4. Richebé $P$, Capdevila $X$, Rivat $C$. Persistent Postsurgical Pain: Pathophysiology and Preventative Pharmacologic Considerations. Anesthesiology. 2018; 129:590-607

5. Tracey I. Imaging pain. Br J Anaesth. 2008;101 (1):32-9.

6. Dîrzu DS, Boṭ T, Ciuce C. Saphenous nerve block as a diagnosis tool for chronic postsurgical pain of the left medial calf. Clin Case Rep. 2018 4;6(2):454-455.

7. Piraccini $E$, Biondi $G$, Byrne $H$, Calli $M$, Bellantonio $D$, Musetti $G$ et al. Ultrasound Guided Transversus Thoracic Plane block, Parasternal block and fascial planes hydrodissection for internal mammary post thoracotomy pain syndrome. Eur J Pain. 2018;22(9):1673-1677.

8. Webster K. The transversus abdominis plane (TAP) block: Abdominal plane regional anaesthesia. Update Anaesth2008;24:25-30.

9. Rafi AN. Abdominal field block: a new approach via the lumbar triangle. Anaesthesia. 2001;56(10):1024-6. doi: 10.1046/j.13652044.2001.02279-40.x.

10. Gürkan Y, Tekin M. Ultrasonografi Rehberliğinde Rejyonal Anestezi. Transversus Abdominis Plan Bloğu [in Turkish]. 2011 ; 145-51

11. Hadzic Periferik Sinir Blokları ve Ultrason Eşliğinde Rejyonal Anestezi İçin Anatomi. Edit. Admir Hadzic. 2. baskı. Ceev.Edit. Ercan Kurt. Ultrason Eşliğinde Sık Kullanılan Trunkal ve Kutanöz Bloklar. [in Turkish]. 2013; 4603.

12. Liu YM, Feng Y, Liu YQ, LV Y, Xiong YC, Ma K, et al. Chinese Association for the Study of Pain:Expert consensus on chronic postsurgical pain. World J Clin Cases. 2021 26;9(9):2090-2099

13. Şahin Ö, Aksoy Y, Kaydu A, Gökçek E. Spinal anestezi uygulanan sezaryen operasyonlarında bilateral TAP bloğun analjezik tüketimine etkisi [in Turkish]. Ortadoğu Tıp Dergisi. 2018; 10(2): 149-153.

14. Theodoraki K, Papacharalampous $P$, Tsaroucha A, Vezakis $A$,
Argyra E. The effect of transversus abdominis plane block on acute and chronic pain after inguinal hernia repair. A randomized controlled trial. Int J Surg. 2019;63:63-70. doi:10.1016/j.jijsu.2019.02.007.

15. Topal A, Sargın M, Kilicaslan A. The Effect of Transversus Abdominis Plane Block in Inguinal Hernioplasty on Chronic Pain. Eur J Gen Med. 2015;12(4), 291-297.

16. Reinoso-Barbero F, Población G, Builes LM, Castro LE, Lahoz Al. Successful ultrasound guidance for transversus abdominis plane blocks improves postoperative analgesia after open appendicectomy in children. Eur J Anaesthesiol. 2012;29(8):402-4.

17. Amr YM, Amin SM. Comparative study between effect of preversus post-incisional transversus abdominis plane block on acute and chronic post-abdominal hysterectomy pain. Anesth Essays Res. $2011 ; 5(1): 77-82$.

18. Mishriky BM, George RB, Habib AS. Transversus abdominis plane block for analgesia after Cesarean delivery: a systematic review and meta-analysis. Can J Anaesth. 2012;59(8):766-78.

19. Abd-Elsayed A, Malyuk D. Efficacy of Transversus Abdominis Plane Steroid Injection for Treating Chronic Abdominal Pain. Pain Pract. 2018;18(1):48-52.

20. Macrae WA. Chronic post-surgical pain: 10 years on. Br J Anaesth. 2008;101(1):77-86.

21. Salaria ON, Kannan M, Kerner B, Goldman H. A Rare Complication of a TAP Block Performed after Caesarean Delivery. Case Rep Anesthesiol. 2017;2017:1072576.

22. Farooq $M$, Carey $M$. A case of liver trauma with a blunt regional anesthesia needle while performing transversus abdominis plane block. Reg Anesth Pain Med. 2008;33(3):274-275. 